\title{
Applicability of Microcellular Injection Molding Process
}

Pavel Brdlík, Vojtěch Rajnoha

Faculty of Engineering Technology. Technical University of Liberec. Studentská 2, 464 17, Liberec. Czech Republic. Email: pavel.brdlik@tul.cz, vojtech.rajnoha@tul.cz

\begin{abstract}
Microcellular injection molding is relatively new and progressive technology for production of lightweight constructions. The weight reduction, elimination of sink marks, internal stresses and deformation of products are the main advantages of this unconventional technology. On the other hand, decrease in mechanical properties and poor surface quality are the application restrictions. There are several aspects affecting formation of microcellular structure and final properties of injection molded products. As a one of the most important aspects there is used material. Therefore, the main goal of this article was investigation the influence of different types of thermoplastic materials on the microcellular structure formation and mechanical properties of products. Further, the influence of holding pressure on products quality was also evaluated.
\end{abstract}

Keywords: Microcellular Injection Molding, Thermoplastic Materials, Microcellular Structure, Mechanical Properties

\section{Introduction}

The microcellular injection molding technology is a production process for thermoplastic products that are characteristic with compact surface and cellular core (skin-core structure). The principle of this unconventional technology consists in saturation polymer melt with physical blowing agents (PBA). The supercritical stage of PBA (the most often $\mathrm{CO}_{2}$ or $\mathrm{N}_{2}$ ) make possible to achieve a single phase solution (uniform distribution of PBA) which is further injected into a mold cavity. Here (due to pressure decrease) the process nucleation, growing and stabilization of cells starts $[1,2]$. The main advantages of microcellular injection molding technology are both economical e.g. products weight reduction (commonly to $40 \%$ ), shorter production time (20-50\%) and also qualitative as e.g. products stress decreasing, flowability increasing, dimensional stability improving, sink marks and warpages elimination $[3,4]$. On the other hand, design limits, poor surface quality and decrease in mechanical properties are the application restrictions $[3,5,6]$. Especially degrease of mechanical properties could be a very important applicability limit in many cases [3]. Mechanical properties of microcellular products are directly determined by formatted cell structure which is influenced by used production conditions (batch of gas, melt temperature, back pressure, injection time, holding pressure, mold temperature, cooling time, etc.) but also by material composition $[1,7]$. The importance of material composition is considerable. It is due to reality that every material has different gas (PBA) diffusion, solubility and cell nucleation properties. If there are compared common semicrystalline (PE, PP) and amorphous materials (PS, PMMA), it could be stated that to achieve good cell structure (enough nucleus), polyolefin materials require higher amounts of gas dosage than amorphous one [1]. Next negative effect of semi-crystalline materials (twophase systems) rests in cell nucleation before the crystallization begins. During the crystallization process, the gas near crystalloids may expel. It could cause cells size increasing and non-uniform structure formation (poor mechanical properties). The amorphous materials have more suitable conditions for nuclei creation and their growth [1]. However, there is one very effective (material) way how to increase cell nuclei number and cell structure uniformity. It is heterogeneous cells nucleation caused by adding fillers as talc or glass fibres $[1,8,9,10]$. Therefore, the goal of this article was to investigate the influence of thermoplastic materials on microcellular structure formation and consequently on mechanical properties of products. Further, the influence of process parameters (holding pressure) on cell structure formation was also investigated.

\section{Experiment}

There are several systems which could provide the technology of microcellular injection molding. There are e.g. MuCell ${ }^{\circledR}$ (developed by Trexel, Inc. Company) or CellMould ${ }^{\circledR}$, ErgoCell, Optifoam ${ }^{\circledR}$, SmartFoam ${ }^{\circledR}$ systems [1]. However, MuCell® has become, due to high uniformity of cell distribution and high repeatability of properties, the most used one. Therefore, just this system integrated to Arburg All - Rounder 470S injection machine was used for evaluation the microcellular injection molding applicability. The selected tested materials were unfiled semi-crystalline copolymer PP Sabic CX03-81, amorphous copolymer ABS Magnum 3616 (used especially for the automotive interior applications) and homopolymer PP Sabic G3230A reinforced with 30\% glass fibres (suitable for the under-the-hood and the structural applications). For proper evaluation of mechanical properties, the standard test specimens ISO 527-2A1 were produced by two process parameters adjustment-shown in Tab.1. The goal of the first process parameters adjustment was not to use any holding pressure, to establish weight reduction cca $10 \%$ and to achieve as good microcellular structure as possible. The goal of the second experimental process adjustment was to investigate the influence of holding pressure (5 seconds) on microcellular structure and consequently on mechanical properties of products.

Next, the product weight, mechanical properties as tensile modulus (ISO 527-1-/-2), tensile strength (ISO $527-1-/-2$ ), tensile strain at break (ISO 527-1-/-2), compressive stress (ISO 178), Charpy impact properties (ISO179-1), hardness (ISO 826:2003) were measured. For evaluation of cell microstructure, SEM images in middle part of test specimens were taken. 
Tab. 1 Used process parameters

\begin{tabular}{|c|c|c|c|c|c|c|c|c|c|}
\hline \multirow[b]{2}{*}{ Parameters } & \multicolumn{3}{|c|}{ PP Sabic CX 0381} & \multicolumn{3}{|c|}{$\begin{array}{c}\text { PP SABIC G3230 A } \\
\text { (30\% of glass fibres) }\end{array}$} & \multicolumn{3}{|c|}{ ABS Magnum 3616} \\
\hline & 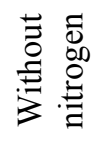 & 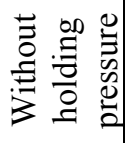 & 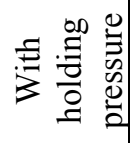 & 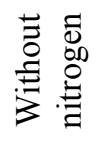 & 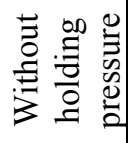 & 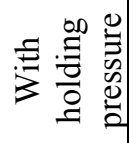 & 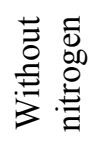 & 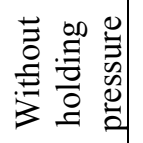 & 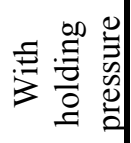 \\
\hline Melt temperature $\left[{ }^{\circ} \mathrm{C}\right]$ & 240 & 240 & 240 & 240 & 240 & 240 & 240 & 240 & 240 \\
\hline Injection speed $\left[\mathrm{cm}^{3} / \mathrm{s}\right]$ & 60 & 60 & 60 & 60 & 60 & 60 & 60 & 60 & 60 \\
\hline Injection volume $\left[\mathrm{cm}^{3} / \mathrm{s}\right]$ & 43 & 33 & 36 & 40 & 30 & 33 & 43 & 33 & 36 \\
\hline Point of switch over[ $\left[\mathrm{cm}^{3}\right]$ & 17 & 1 & 1 & 13 & 1 & 1 & 17 & 1 & 1 \\
\hline Holding pressure time $[\mathrm{s}]$ & 15 & 0 & 5 & 15 & 0 & 5 & 15 & 0 & 5 \\
\hline Holding pressure [Bars] & 350 & 0 & 200 & 350 & 0 & 300 & 350 & 0 & 200 \\
\hline Decompress volume $\left[\mathrm{cm}^{3}\right]$ & 0 & 0 & 0 & 0 & 0 & 0 & 0 & 0 & 0 \\
\hline Back pressure [Bars] & 0 & 100 & 100 & 0 & 100 & 100 & 0 & 100 & 100 \\
\hline Water temperature $\left[{ }^{\circ} \mathrm{C}\right]$ & 40 & 40 & 40 & 40 & 40 & 40 & 40 & 40 & 40 \\
\hline Water flow rate $[1 / \mathrm{min}]$ & 10 & 10 & 10 & 10 & 10 & 10 & 10 & 10 & 10 \\
\hline Clamping force [kN] & 1000 & 1000 & 1000 & 1000 & 1000 & 1000 & 1000 & 1000 & 1000 \\
\hline $\begin{array}{l}\text { Mass percentage of the } \\
\text { Nitrogen }[\%]\end{array}$ & 0.0 & 0.3 & 0.3 & 0.0 & 0.3 & 0.3 & 0.0 & 0.3 & 0.3 \\
\hline Cycle time $[\mathrm{s}]$ & 60 & 60 & 60 & 60 & 60 & 60 & 60 & 60 & 60 \\
\hline
\end{tabular}

\section{Results and discussion}

The microcellular structure of the experimental production is shown in Fig. 1, 2 and 3. From SEM images of unfilled PP SabixCX 03-81, the low quality of cell structure is obvious. In the core, there are randomly occurred groups of cells with periodic shape and characteristic radius size $0.01 \mathrm{~mm}$. There are cells with wide $0.08 \mathrm{~mm}$ and length $0.6 \mathrm{~mm}$ in the middle part. This shape distortion is caused by cell coalescence. The cell coalescence, also as detected cell agglomeration, could have a very negative effect on the mechanical properties. The microcellular structure of reinforced PP Sabic G3230A with $30 \%$ of glass fibres was, due to the heterogeneous cells nucleation effect, much better. Distribution of cells was regular, structure consisted of high number of cells, even very close to the surface. As a characteristic cells size there was radius $0.06 \mathrm{~mm}$ in the core and radius 0.02 $\mathrm{mm}$ close to surface. Therefore, it is possible to suppose better mechanical properties (lower decrease in comparing to the solid material) than for unfilled PP. Also in test specimens production made from amorphous ABS Magnum 3616 was detected much better microcellular structure than in unfilled PP. In the core was measured characteristic radius size $0.05 \mathrm{~mm}$ and in the next layer radius $0.01 \mathrm{~mm}$. From SEM images it is also obvious that the cell structure distribution was not as uniform as cell structure of PP reinforced with glass fibres. If there are compared different process adjustments of PP, it is possible to state that applying of holding pressure in mold cavity caused cells size decreasing. It could have positive effect to mechanical properties but also to the decrees reduction of product weight. The different results were detected in amorphous material ABS Magnum 3616. The cell structure contained the low number of cells with bigger radius (characteristic cells size radius $0.16 \mathrm{~mm}$ ).

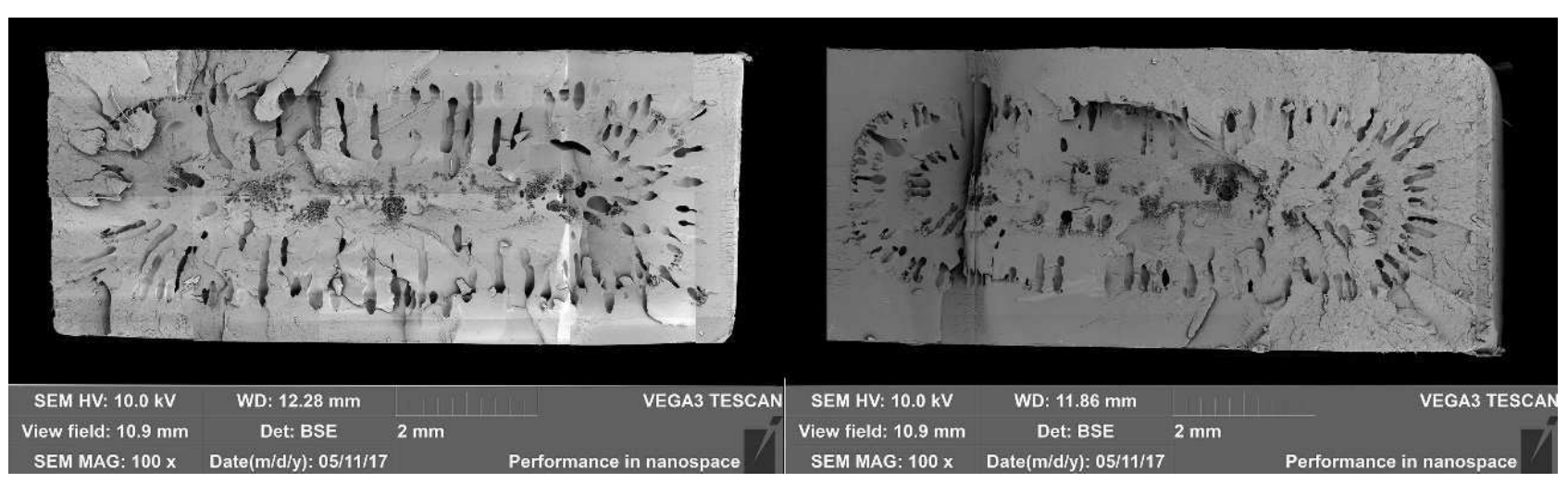

Fig. 1 SEM images of unfilled semicristal PP Sabic CX 0381 (left-without holding pressure, right - with holding pressure (5 seconds) 


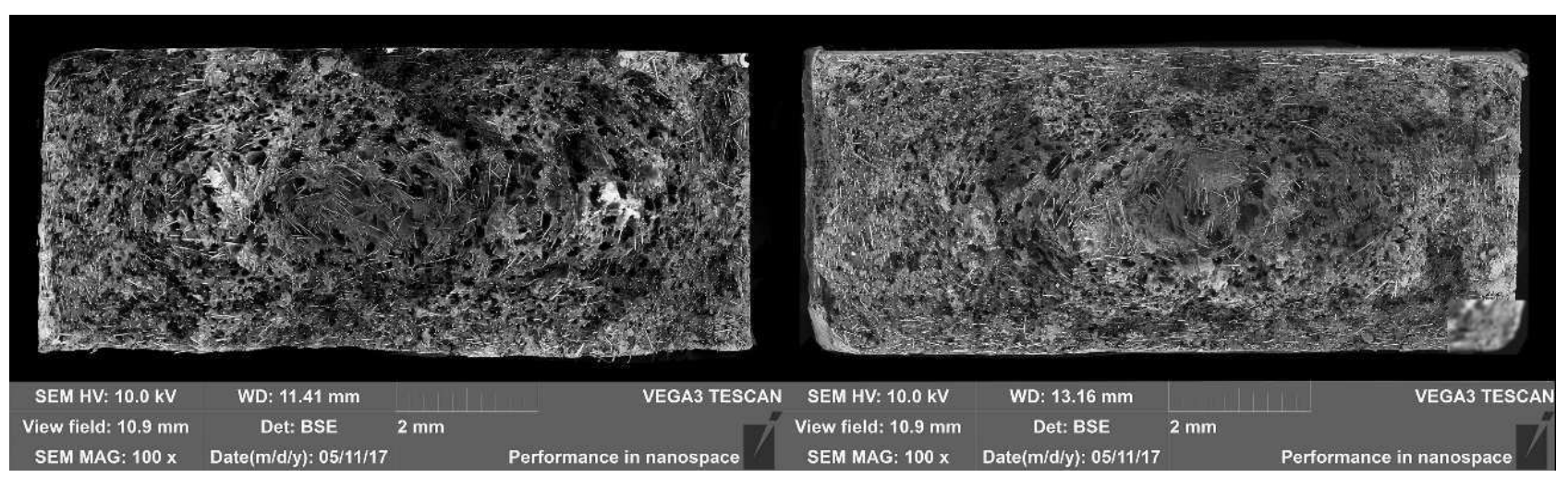

Fig. 2 SEM images of filled PP Sabic G3230 (left-without holding pressure, right - with holding pressure)

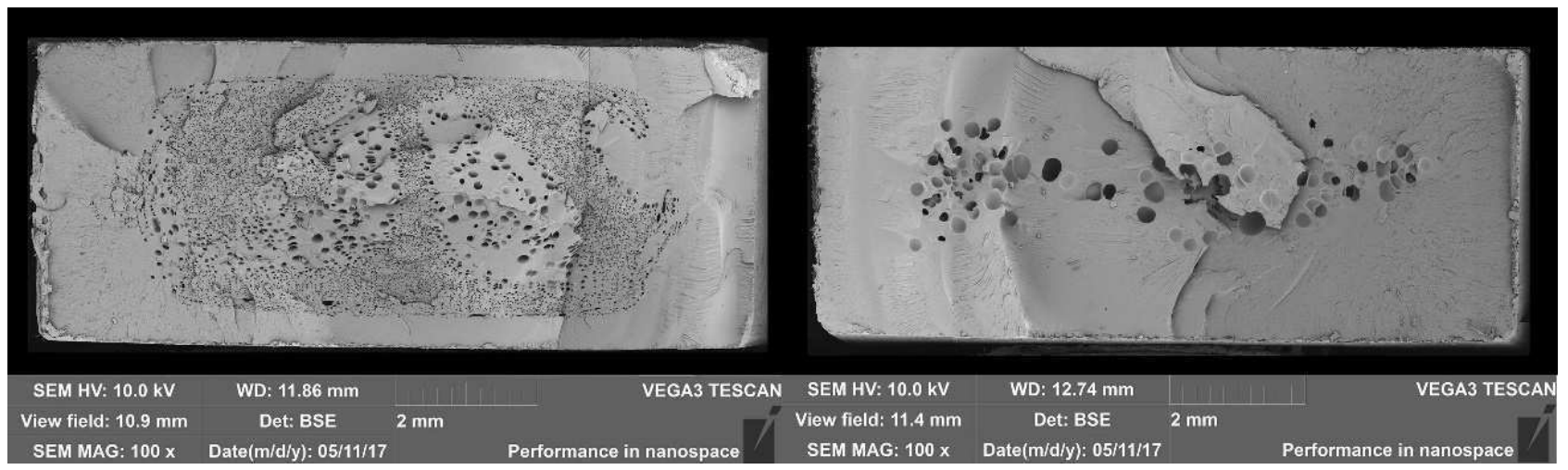

Fig. 3 SEM images of amorphous ABS Magnum 3616 (left-without holding pressure, right - with holding pressure)

Tab. 2 Decrease of mechanical properties

\begin{tabular}{|c|c|c|c|c|c|c|c|}
\hline \multicolumn{2}{|c|}{} & \multicolumn{2}{|c|}{ PP Sabic CX03-81 } & \multicolumn{2}{c|}{ PP Sabic G3230A } & \multicolumn{2}{|c|}{ ABS Magnum G3616 } \\
\hline $\begin{array}{c}\text { Degrease of } \\
\text { properties }\end{array}$ & Standard & $\begin{array}{c}\text { Without } \\
\text { holding } \\
\text { pressure }\end{array}$ & $\begin{array}{c}\text { With } \\
\text { holding } \\
\text { pressure }\end{array}$ & $\begin{array}{c}\text { Without } \\
\text { holding } \\
\text { pressure }\end{array}$ & $\begin{array}{c}\text { With } \\
\text { holding } \\
\text { pressure }\end{array}$ & $\begin{array}{c}\text { Without } \\
\text { holding } \\
\text { pressure }\end{array}$ & $\begin{array}{c}\text { With } \\
\text { holding } \\
\text { pressure }\end{array}$ \\
\hline Weight & - & $8.9 \%$ & $4.1 \%$ & $10.9 \%$ & $5.0 \%$ & $8.1 \%$ & $3.7 \%$ \\
\hline $\begin{array}{c}\text { Tensile } \\
\text { modulus }\end{array}$ & $\begin{array}{c}\text { ISO } \\
527-1-/-2\end{array}$ & $25.2 \%$ & $19.5 \%$ & $17.9 \%$ & $16.4 \%$ & $18.6 \%$ & $12.1 \%$ \\
\hline $\begin{array}{c}\text { Tensile stren- } \\
\text { gth }\end{array}$ & $\begin{array}{c}\text { ISO } \\
527-1-/-2\end{array}$ & $30.2 \%$ & $22.8 \%$ & $23.3 \%$ & $22.9 \%$ & $20.9 \%$ & $14.5 \%$ \\
\hline $\begin{array}{c}\text { Tensile strain } \\
\text { at break }\end{array}$ & ISO 527-1-/-2 & $6.5 \%$ & $4.8 \%$ & $3.6 \%$ & $3.2 \%$ & $2.0 \%$ & $1.2 \%$ \\
\hline $\begin{array}{c}\text { Compressive } \\
\text { stress }\end{array}$ & ISO 178 & $17.6 \%$ & $16.2 \%$ & $15.0 \%$ & $13.9 \%$ & $6.8 \%$ & $3.7 \%$ \\
\hline $\begin{array}{c}\text { Charpy impact } \\
\text { strength }\end{array}$ & ISO 179-1 & $43.1 \%$ & $35.7 \%$ & $17.9 \%$ & $10.6 \%$ & $9.3 \%$ & $6.9 \%$ \\
\hline Hardness & ISO868:2003 & $1.3 \%$ & $0.3 \%$ & $1.1 \%$ & $0.8 \%$ & $2.0 \%$ & $1.5 \%$ \\
\hline
\end{tabular}

In Tab. 2 are compared the achieved weight reductions and decreases in mechanical properties (comparing to the test specimens without PBA). As it was predicted from SEM images, the highest decrease in mechanical properties was detected for unfilled PP Sabic G3230. The Charpy impact properties, tensile modulus and tensile strength decreases were expressive (higher than 25\%). Only for the hardness, it could be stated that there are not any significant differences. Lower cells size and more uniform structures of reinforcement PP Sabic G3230 and ABS Magnum 3616 caused lower decrease of mechanical properties. But the decreases in mechanical properties were still very expressive. The evaluated mechanical properties of process variants where was used holding pressure (for 5 seconds), show a little lower decreases of mechanical properties (due to lower cell size) that is a positive effect. On the other hand, the weight reduction (economical aspect) is nearly half than in the previous adjustment (without holding pressure).

\section{Conclusion}

The microcellular injection molding is a relative new progressive technology, which could ensure both economical and product quality benefits. As the main disadvantages there are decreases of mechanical properties and poor surface quality. Therefore, the goal of this article was to determine the influence of thermoplastic materials 
(semicrystalline, amorphous and filled) and process parameters (holding pressure) on microcellular structure formation and consequently also on mechanical properties of products. From evaluated structure imagines is obvious that the worse microcellular structure was detected for unfilled semicrystalline PP Sabic CX 0381. The agglomeration and coalescence effects caused expressive decrease of mechanical properties (Charpy impact properties, tensile strength, tensile modulus and compressive stress). Much better cells structures (uniform distribution of cells and the periodic shape of cells radius) were detected in amorphous (ABS Magnum G3616) and reinforced (PP Sabic G3230 A) materials. However, it is important to state that also here was detected considerable decrease of mechanical properties. Therefore, it could be confirmed that decreases of mechanical properties are in some applications the limitation of this unconventional technology. Further it was detected that the use of holding pressure causes cells size formation restriction and consequently the lower weight reduction. The decrease of mechanical properties was also expressive in this process adjustment.

\section{Acknowledgement}

This publication was written at the Technical University of Liberec as part of the Student Grant Contest "SGS 21122" with the support of the Specific University Research Grant, as provided by the Ministry of Education, Youth and Sports of the Czech Republic in the year 2018.

\section{References}

[1] XU, J. (2010). Microcellular Injection Molding, pp. 13-24, 110-177, 227-314. John Wiley \& Sons Inc., Hoboken, New Jersey, USA. ISBN 978-0470-46612-4.

[2] LEE, S. T. (2005), Thermoplastic Foam Processing, pp. 39-47, 70-84. CRC Press, New York, USA. ISBN 0-8493-1701-0.

[3] HEIM, H. P. (2016). Specialize Injection Molding Techniques, pp. 53-100. Elsevier Ing., Oxford, UK. ISBN 978-0-323-34100-4.

[4] KRAMSCHUSTER, A., CAVITT, R., ERMER, D., CHEN, Z., TURNG, L.S. (2005). Quantitative
Study of Shrinkage and Warpage Behavior for Microcellular and Conventional Injection molding. In: Polmyer Engineering \& Science, pp. 1408-1418. John Wiley \& Sons Inc., Hoboken, New Jersey, USA.

[5] ZHANG, L., ZHAO, G., DONG, G., LI, S., WANG, G. (2015). Bubble Morphological Evolution and Surface Defect Formation Mechanism in the Microcellular Foam Injection Molding Process. In: RSC Advances, Vol. 5, No. 86, pp. 7003270050. Royal Society of Chemistry. ISSN 20462069.

[6] BÍlEK, O., FOJTL, L., PATA, V., COP, J. (2016). Supramolecular Structure of Polymers and Its Effect on Surface Quality of Injection Molded Parts Using Various Surface Quality of Cavities. In: Manufacturing Technology, Vol. 16, No. 5, pp. 874-879. Univerzita J. E. Purkyne., Czeh republic. ISSN 12132489.

[7] GUO, W., MAOA, H., LIA, B., GUO, X. (2014). Influence of Processing Parameters on Molding Process in Microcellular Injection Molding. In: Proceedings of $11^{\text {th }}$ International Conference on Technology of Plasticity, Vol. 81, pp. 670-675. Nagoya Congress Center, Nagoya, Japan. ISSN 18777058.

[8] GÓMEZ-MONTERDE, J., SÁNCHEZ-SOTO, M., MASPOCH, M. L. (2018). Microcellular PP/GF composites: Morphological, mechanical and fracture characterization. In: Proceedings Applied Science and Manufacutring. Vol. 104, pp. 1-13. Elsevier Ltd.

[9] KALOVÁ, M., RUSKOVÁ, S. (2017). Microstructure of polymer composite materials. In: Manufacturing Technology. Vol. 17, pp. 722728. ISSN 12132489.

[10] JAKUBÍČEK, J., et al (2016). The Influence of nucleating agents and process parameters on phase structure of isotactic polypropylene and its Copolymer with 3\% ethylene. In: Manufacturing Technology. ISSN 12132489. 